UDC 616.5

DOI: $10.15587 / 2519-4798.2017 .99219$

\title{
EFFECT OF MILK AND DAIRY PRODUCTS CONSUMPTION ON ACNE RISK AND SEVERITY IN YOUNG ADULT PATIENTS WITH ACNE VULGARIS ATTENDING THE DERMATOLOGY CLINICS AT KING FAHD HOSPITAL OF THE UNIVERSITY IN ALKHOBAR, SAUDI ARABIA
}

\author{
(C) H. Alghamdi, A. M. Alhemel, I. A. Bukhari \\ У представленому дослідженні було вивчено взаємозв'язок між споживанням молока та молочних продук- \\ тів на ризик виникнення та важкість перебігу акне у пацієнтів підліткового віку з Acnе vulgaris. 3 метою \\ дослідження було здійснено анкетування щзодо споживання молочних продуктів та оцінку ступеня тяж- \\ кості акне за допомогою Глобальної системи класифікації акне. Було встановлено, щуо немає статистич- \\ но значущеоі різниці між важкістю перебігу акне та всіх харчових факторів, окрім споживання молока. \\ В результаті проведеного дослідження можна припустити, щзо споживання молочних продуктів, окрім \\ молока, не впливає та не викликає загострення акне
}

Ключові слова: акне, молоко, молочні продукти, комедогенез, літогенез, сальні залози, запалення, андрогени, дієта, харчування

\section{Introduction}

Acne vulgaris is a common cutaneous disorder. Its prevalence is up to $80 \%$ in the majority of countries worldwide [1]. There are multiple factors that play a role in acne which include genetic, hormonal and stress. According to one study $85 \%$ of the teenagers are likely to suffer from acne outbreaks between the ages 12 to 25 years among whom $25 \%$ could progress to permanent scarring [2]. The relationship between acne and dairy products has been documented in the medical literature. We will assess this relationship in our study.

\section{Statement of research}

Many studies were done questioning the relationship between acne and diet especially dairy products. Some have shown controversial results. The most recent study was a Cross-sectional study of 182 participants in Kazakhstan in which the daily consummation of milk and dairy products was assessed. It was found that the risk of acne occurrence is significantly higher $(p<0,001)$ in people with the highest milk and dairy product consumption level [3]. There is substantial epidemiological and biochemical evidence supporting the effects of milk and dairy products as enhancers of insulin-like growth factor 1 (IGF-1) signaling which is a one of several factors that cause inflammation in humans and eventually lead to acne presentation and aggravation [4]. In Saudi Arabia, a study on the influence of milk and milk products on the risk and severity of acne in young people was never done. So the aim of this study was to assess the relation between dairy products and acne risk and severity among young adult patients attending the dermatology clinics at King Fahd Hospital of the University (KFHU) in Alkhobar, Saudi Arabia.

\section{Aim of research}

Assess the relation between dairy products and acne risk and severity among young adult patients attending the dermatology clinics at King Fahd Hospital of the University (KFHU) in Alkhobar, Saudi Arabia.

\section{Methods}

This is a case control study using interview questionnaire conducted at the dermatology clinics at King Fahd Hospital of the University in Alkhobar, Saudi Arabia during a period of one year (March 2015-April 2016). After acquiring the Institutional Review Board approval (license number IRB-2015-01-064) the study was initiated. All the information from the questionnaire was kept confidential. Written informed consent was taken before the respondent involvement in the study. Variable were adapted from previous study [5] and shown in Table 1. A total of 100 (27 male, 73 female) participants were involved in the study (50 cases and 50 controls). Our inclusion criteria was all adolescent and young adult patients (age 12-25 years) diagnosed with acne vulgaris at KFHU. Exclusion criteria included the presence of other medical conditions such poly cystic ovarian syndrome, Cushing syndrome, acne rosacea, steroid intake and incompletely answered questionnaire. Participants were interviewed using a food frequency questionnaire and asked how frequently they used a typical portion size of specified foods during the past 6 months, types of milk that was consumed and if they consumed other type of food with high glycemic index (Table 1). Clinical examination to assess the severity of acne was done by a dermatologist using the global acne grading system (Table 2).

Anthropometric measurements was taken using Seca digital scale with height rod. The raw data was processed and entered for data analysis as soon as it was collected from the participants. The collected data was entered into SPSS (Statistical Package for Social Sciences) version 16.0 for analysis. Descriptive statistics were reported using frequency and percentages for all categorical variables, and for continuous variables Mean \pm S. D were used for normally distributed data and median and interquartile range for skewed data. Chi-square test or a fisher's exact tests for categorical data were used to assess the association of the explanatory variables with cases and controls. Independent sample t test for con- 
tinuous data and Mann-Whitney U Test for skewed data were used to compare the difference in the explanatory variables between cases and control. Univariate logistic regression of all significant factors from the associations test were performed, followed by a multivariate logistic regression analysis on the all significant risk factors.

Table 1

Variables used in this study

\begin{tabular}{|c|c|c|}
\hline Variable* & Definition & Scale \\
\hline Age & $\begin{array}{l}\text { Participant age calculat- } \\
\text { ed from date of birth till } \\
\text { the day of questionnaire } \\
\text { collection }\end{array}$ & Years \\
\hline Sex & $\begin{array}{l}\text { Answers provided to specif- } \\
\text { ic question in questionnaire. }\end{array}$ & $\begin{array}{l}\text { Questionnaire } \\
\text { - Male } \\
\text { - Female }\end{array}$ \\
\hline Wt. & $\begin{array}{l}\text { Participant wt measured by } \\
\text { the researcher using a scale } \\
\text { in the hospital at the day of } \\
\text { questionnaire collection }\end{array}$ & $\mathrm{Kg}$ \\
\hline $\mathrm{Ht}$ & $\begin{array}{l}\text { Participant ht measured } \\
\text { by the researcher using a } \\
\text { body meter in the hospital } \\
\text { at the day of questionnaire } \\
\text { collection }\end{array}$ & $\mathrm{Cm}$ \\
\hline $\begin{array}{l}\text { Dairy Con- } \\
\text { sumption }\end{array}$ & $\begin{array}{l}\text { The Type } \& \text { frequency of } \\
\text { dairy product Consumption }\end{array}$ & $\begin{array}{l}\text { Food frequency } \\
\text { questionnaire }\end{array}$ \\
\hline $\begin{array}{l}\text { Milk } \\
\text { Consump- } \\
\text { tion }\end{array}$ & $\begin{array}{l}\text { The Type of } \\
\text { Milk Consumption }\end{array}$ & $\begin{array}{l}\text { Food frequency } \\
\text { questionnaire }\end{array}$ \\
\hline $\begin{array}{l}\text { Food with } \\
\text { high glyce- } \\
\text { mic index }\end{array}$ & $\begin{array}{l}\text { Participant intake of white } \\
\text { bread, rice, chocolate, } \\
\text { French fries \& Pizza. }\end{array}$ & $\begin{array}{l}\text { Questionnaire } \\
\text { - Yes } \\
\text { - No }\end{array}$ \\
\hline $\begin{array}{l}\text { Acne sever- } \\
\quad \text { ity }\end{array}$ & $\begin{array}{l}\text { The severity of acne as } \\
\text { calculated by the treating } \\
\text { physician after a clinical ex- } \\
\text { amination using the Global } \\
\text { acne grading system. }\end{array}$ & $\begin{array}{l}\text { Questionnaire } \\
\text { - Mild } \\
\text { - Moderate } \\
\text { - Sever } \\
\text { - Very sever }\end{array}$ \\
\hline
\end{tabular}

Note: * - Variables adapted from reference 10
Table 2

Global acne grading system

\begin{tabular}{|c|c|}
\hline Location & Factor \\
\hline Forehead & 2 \\
\hline Right cheek & 2 \\
\hline Left cheek & 2 \\
\hline Nose & 1 \\
\hline Chin & 1 \\
\hline Chest and upper back & 3 \\
\hline
\end{tabular}

Note: each type of a lesion is given a value depending on severity, no lesion $=0$, comedones $=1$, papules $=2$, and nodules $=4$. The score for each area is calculated using the formula: local score $=$ factor $*$ grading $(0-4)$. The global score is the sum of local scores, and acne severity was graded using the global score. A score of 1-18 is considered mild; 19-30 moderate, severe and $>39$, very severe

\section{Results}

There was similar gender distribution between the cases and controls. Their ages varied between 13 to 25 years. However, there was a statistically significant difference in the age, between the cases and the controls $(p=0.005)$ showing that cases group had younger ages than the controls. In other words, the mean age of females in the case group was $(20.5 \pm 3.2)$ which is significantly lower as compared to female in the control group $(22.4 \pm 2.2) \quad(p=0.004)$. No statistically significant difference $(p<0.05)$ between the cases and control groups in weight body mass index and height for both sexes.

After adjusting for other predictors, the risk of acne increased with increasing age; OR (odds ratio) $=1.39$; $95 \%$ CI (confidence interval: 1.14-1.68) $(\mathrm{p}=0.001)$. In case the subject consumes French fries, there is a fivefold greater risk for acne (OR=4.60; $95 \% \mathrm{CI}$ : 1.21-17.51) $(\mathrm{p}=0.025)$. If butter is consumed more than once a week the risk for acne increased $(\mathrm{OR}=3.76$; $95 \% \mathrm{CI}$ : $1.21-$ 11.62) $(\mathrm{p}=0.022)$. No statistically significant difference $(\mathrm{P}<0.05)$ was found between the severity of acne with all the dietary factors for the cases except for consumption of milk $(\mathrm{p}=0.033)$ (Table 3).

Table 3

The statistical significance between acne severity and dietary factors

\begin{tabular}{|c|c|c|c|c|c|}
\hline \multirow{2}{*}{ Characteristic n $(\%)$} & \multicolumn{3}{|c|}{ Acne severity } & \multirow{2}{*}{ Chisquare } & \multirow{2}{*}{$P$ value } \\
\hline & Mild & Moderate/severe & Overall & & \\
\hline 1 & 2 & 3 & 4 & 5 & 6 \\
\hline Sex & & & & & \\
\hline Male & $2(10.0)$ & $8(26.7)$ & $10(20.0)$ & $2.083^{\#}$ & 0.279 \\
\hline Female & $18(90.0)$ & $22(73.3)$ & $40(80.0)$ & & \\
\hline \multicolumn{6}{|l|}{ Milk } \\
\hline$>=2$ day & $4(20.0)$ & $3(10.0)$ & $7(14.0)$ & & \\
\hline 1 day & $1(5.0)$ & $9(30.0)$ & $10(20.0)$ & $8.479^{\#}$ & 0.033 \\
\hline $2-6$ week & $9(45.0)$ & $5(16.7)$ & $14(28.0)$ & & \\
\hline$=<1$ week & $6(30.0)$ & $13(43.3)$ & $19(38.0)$ & & \\
\hline
\end{tabular}




\begin{tabular}{|c|c|c|c|c|c|}
\hline 1 & 2 & 3 & 4 & 5 & 6 \\
\hline \multicolumn{6}{|c|}{ Chocolate milk } \\
\hline$>=2$ day & - & - & - & \multirow{4}{*}{$2.486^{\#}$} & \multirow{4}{*}{0.259} \\
\hline 1 day & $0(0.0)$ & $3(10.0)$ & $3(6.0)$ & & \\
\hline $2-6$ week & $4(20.0)$ & $3(10.0)$ & $7(14.0)$ & & \\
\hline$=<1$ week & $16(80.0)$ & $24(80.0)$ & $40(80.0)$ & & \\
\hline \multicolumn{6}{|l|}{ Ice cream } \\
\hline$>=2$ day & $1(5.0)$ & $1(3.3)$ & $2(4.0)$ & \multirow{4}{*}{$1.039^{\#}$} & \multirow{4}{*}{0.935} \\
\hline 1 day & $1(5.0)$ & $1(3.3)$ & $2(4.0)$ & & \\
\hline $2-6$ week & $5(25.0)$ & $6(20.0)$ & $11(22.0)$ & & \\
\hline$=<1$ week & $13(65.0)$ & $22(73.3)$ & $35(70.0)$ & & \\
\hline \multicolumn{6}{|l|}{ Yogurt } \\
\hline$>=2$ day & $1(5.0)$ & $1(3.3)$ & $2(4.0)$ & \multirow{4}{*}{$2.431^{\#}$} & \multirow{4}{*}{0.493} \\
\hline 1 day & $1(5.0)$ & $6(20.0)$ & $7(14.0)$ & & \\
\hline $2-6$ week & $8(40.0)$ & $10(33.3)$ & $18(36.0)$ & & \\
\hline$=<1$ week & $10(50.0)$ & $13(43.3)$ & $23(46.0)$ & & \\
\hline \multicolumn{6}{|c|}{ Halloumi cheese } \\
\hline$>=2$ day & - & - & - & \multirow{4}{*}{$2.328^{\#}$} & \multirow{4}{*}{0.361} \\
\hline 1 day & $0(0.0)$ & $3(10.0)$ & $3(6.0)$ & & \\
\hline 2-6 week & $2(10.0)$ & $5(16.7)$ & $7(14.0)$ & & \\
\hline$=<1$ week & $18(90.0)$ & $22(73.3)$ & $40(80.0)$ & & \\
\hline \multicolumn{6}{|l|}{ Cream cheese } \\
\hline$>=2$ day & - & - & - & \multirow{4}{*}{2.129} & \multirow{4}{*}{0.345} \\
\hline 1 day & $3(15.0)$ & $10(33.3)$ & $13(26.0)$ & & \\
\hline 2-6 week & $9(45.0)$ & $10(33.3)$ & $19(38.0)$ & & \\
\hline$=<1$ week & $8(40.0)$ & $10(33.3)$ & $18(36.0)$ & & \\
\hline \multicolumn{6}{|l|}{ Hard cheese } \\
\hline$>=2$ day & - & - & & \multirow{4}{*}{$1.665^{\#}$} & \\
\hline 1 day & $3(15.0)$ & $9(30.0)$ & $12(24.0)$ & & \multirow{3}{*}{0.433} \\
\hline $2-6$ week & $3(15.0)$ & $5(16.7)$ & $8(16.0)$ & & \\
\hline$=<1$ week & $14(70.0)$ & $16(53.3)$ & $30(60.0)$ & & \\
\hline \multicolumn{6}{|l|}{ Milk shake } \\
\hline$>=2$ day & $1(5.0)$ & - & $1(2.0)$ & \multirow{4}{*}{$2.450^{\#}$} & \multirow{4}{*}{0.617} \\
\hline 1 day & - & $1(3.3)$ & $1(2.0)$ & & \\
\hline 2-6 week & $3(15.0)$ & $3(10.0)$ & $6(12.0)$ & & \\
\hline$=<1$ week & $16(80.0)$ & $26(86.7)$ & $42(84.0)$ & & \\
\hline \multicolumn{6}{|l|}{ Butter } \\
\hline$>=2$ day & - & - & - & & \\
\hline 1 day & $1(5.0)$ & $3(10.0)$ & $4(8.0)$ & \multirow{3}{*}{$1.254^{\#}$} & \\
\hline $2-6$ week & $3(15.0)$ & $2(6.7)$ & $5(10.0)$ & & 0.644 \\
\hline$=<1$ week & $16(80.0)$ & $25(83.3)$ & $41(82.0)$ & & \\
\hline Type of milk & & & & & \\
\hline Whole & $9(45.0)$ & $14(46.7)$ & $23(46.0)$ & & \\
\hline Low fat & $9(45.0)$ & $10(33.3)$ & $19(38.0)$ & & \\
\hline Skimmed & - & $1(3.3)$ & $1(2.0)$ & $4.380^{\#}$ & 0.341 \\
\hline Don't know & $2(10.0)$ & $1(3.3)$ & $3(6.0)$ & & \\
\hline Don't drink & - & $4(13.3)$ & $4(8.0)$ & & \\
\hline
\end{tabular}


Continuation Table 3

\begin{tabular}{|c|c|c|c|c|c|}
\hline 1 & 2 & 3 & 4 & 5 & 6 \\
\hline \multicolumn{6}{|l|}{ French Fries } \\
\hline Yes & $16(80.0)$ & $21(70.0)$ & $37(74.0)$ & 0.624 & 0.430 \\
\hline No & $4(20.0)$ & $9(30.0)$ & $13(26.0)$ & & \\
\hline \multicolumn{6}{|l|}{ Pizza } \\
\hline Yes & $14(70.0)$ & $22(73.3)$ & $36(72.0)$ & 0.066 & 0.797 \\
\hline No & $6(30.0)$ & $8(26.7)$ & $14(28.0)$ & & \\
\hline \multicolumn{6}{|l|}{ Chocolate } \\
\hline Yes & $17(85.0)$ & $25(83.3)$ & $42(84.0)$ & $0.025^{\#}$ & 1.000 \\
\hline No & $3(15.0)$ & $5(16.7)$ & $8(16.0)$ & & \\
\hline \multicolumn{6}{|l|}{ Rice } \\
\hline Yes & $17(85.0)$ & $25(83.3)$ & $42(84.0)$ & $0.025^{\#}$ & 1.000 \\
\hline No & $3(15.0)$ & $5(16.7)$ & $8(16.0)$ & & \\
\hline \multicolumn{6}{|l|}{ White bread } \\
\hline Yes & $16(80.0)$ & $25(83.3)$ & $41(82.0)$ & $0.090^{\#}$ & 1.000 \\
\hline No & $4(20.0)$ & $5(16.7)$ & $9(18.0)$ & & \\
\hline
\end{tabular}

Note: \#-Fisher exact test

\section{Discussion}

This case control study was conducted at the dermatology clinics at King Fahd Hospital of the University in Alkhobar, Saudi Arabia for a period of one year starting March 2015 to April 2016 to assess the relation between dairy products consumption and acne risk and severity in young adult patients with acne using interview questionnaires. After adjusting for other predictors, the risk of acne increased with increasing age $(\mathrm{OR}=1.39 ; 95 \%$ CI: $1.14-1.68)(p=0.001)$. There was no statistically significant difference $(\mathrm{P}<0.05)$ found between the severity of acne with all the dietary factors including chocolate milk, ice cream, yogurt, halloumi cheese, cream cheese, hard cheese, milk shake, butter, type of milk, french fries, pizza, chocolate, rice, white bread except for consumption of milk which was $\chi^{2}(3,50)=8.479(\mathrm{p}=0.033)$. This contradicts the findings in other similar studies done in the world who found a strong correlation between milk and dairy product consumption and the risk of acne development [3, 5-10]. However, butter, rice and french fries were positively associated with increased risk for acne. Specifically patients consuming french fries had a fivefold greater risk $(\mathrm{OR}=4.60 ; 95 \% \mathrm{CI}$ : $1.21-17.51)(\mathrm{p}=0.025)$ for acne compared to the controls. Pathophysiologically, milk consumption significantly elevates insulin and IGF-1 (Insulin growth factor 1 ) levels and decreases IGFBP-3 levels [11]. it also contains bovine IGF-1, which is identical to human IGF-1 and binds with the same affinity to its receptor [12]. Increased insulin and IGF-1 signaling promote comedogenesis, sebaceous lipogenesis, follicular inflammation, and androgenic stimulation [13]. Milk also contains dihydrotestosterone precursors, including placenta-derived progesterone, 5a-pregnanedione, 5a-androstanedione, and numerous growth-related factors which in turn aggrevate acne [14]. Only the frequency of milk consumption was positively associated with acne severity while the type of milk made no statistically significant difference. This is partially similar to the findings in the Egyptian study done by saleh et al on a 100 acne patients assessing the relationship between the dietary intake of acne patients and acne severity [15]. The most notable limitations of this study were the retrospective self-reported dairy product consumption and data was not adjusted for some important confounding variables (such as stress, inadequate sleep, smoking, family history of acne). There are multiple randomized controlled trials that have shown the benefit of a low glycemic index/glycemic load diet in treating acne so this diet may be recommended to patients [16-19]. While observational studies support the link between milk and acne, multiple randomized controlled trial are required before milk restriction diets can be recommended to acne patients.

\section{Conclusion}

1. Dairy products consumption does not seem to influence or aggravate acne development in our young adults who were Saudis except for milk.

2. Randomized controlled trials are highly recommended to establish a causal relationship between frequent milk consumption and acne severity and to assess the role of medical nutrition therapy (MNT) in acne management.

3. A practical approach is to address each acne patient individually and consider the possibility of dietary counseling.

\section{Acknowledgements}

We would like to give our thanks to Dr. Abdullah Aljoudi in the Community Medicine Department at King Fahd Hospital of the University and all the participants involved in this study and to the staff members of Department of Dermatology at King Fahd Hospital of the University. We also would like to acknowledge Dr. Abeer Alghwairi effort in data collection. 


\section{References}

1. Dreno, B. Recent data on epidemiology of acne [Text] / B. Dreno // Annales de Dermatologie et de Venereologie. - 2010. Vol. 137, Issue 12. - P. 3-5. doi: 10.1016/s0151-9638(10)70045-4

2. Zubair, N. Acne and dairy products [Text] / N. Zubair, M. N. Zubair // Journal of the Pakistan Medical Association. 2011. - Vol. 61, Issue 9. - P. 948.

3. Tsoy, N. O. Effect of Milk and Dairy Products upon Severity of Acne for Young People [Text] / N. O. Tsoy // World Applied Sciences Journal. - 2013. - Vol. 24, Issue 3. - P. 403-407.

4. Melnik, B. Diet in acne: further evidence for the role of nutrient signalling in acne pathogenesis [Text] / B. Melnik // Acta Dermato Venereologica. - 2012. - Vol. 92, Issue 3. - P. 228-231. doi: 10.2340/00015555-1358

5. Adebamowo, C. A. Milk consumption and acne in teenaged boys [Text] / C. A. Adebamowo, D. Spiegelman, C. S. Berkey, F. W. Danby, H. H. Rockett, G. A. Colditz et. al. // Journal of the American Academy of Dermatology. - 2008. - Vol. 58, Issue 5. P. 787-793. doi: 10.1016/j.jaad.2007.08.049

6. Ismail, N. H. High glycemic load diet, milk and ice cream consumption are related to acne vulgaris in Malaysian young adults: a case control study [Text] / N. H. Ismail, Z. A. Manaf, N. Z. Azizan // BMC dermatology. - 2012. - Vol. 12, Issue 1. P. 13. doi: 10.1186/1471-5945-12-13

7. Burris, J. Relationships of self-reported dietary factors and perceived acne severity in a cohort of New York young adults [Text] / J. Burris, W. Rietkerk, K. Woolf // Journal of the Academy of Nutrition and Dietetics. - 2014. - Vol. 114, Issue 3. - P. 384-392. doi: 10.1016/j.jand.2013.11.010

8. Adebamowo, C. A. High school dietary dairy intake and teenage acne [Text] / C. A. Adebamowo, D. Spiegelman, F. W. Danby, A. L. Frazier, W. C. Willett, M. D. Holmes // Journal of the American Academy of Dermatology. - 2005. - Vol. 52, Issue 2. - P. 207-214. doi: 10.1016/j.jaad.2004.08.007

9. Adebamowo, C. A. Milk consumption and acne in adolescent girls [Electronic resources] / C. A. Adebamowo, D. Spiegelman, C. S. Berkey, F. W. Danby, H. H. Rockett, G. A. Colditz et. al. // Dermatology Online Journal. - 2006. - Vol. 12, Issue 4. - Available at: https://www.ncbi.nlm.nih.gov/pubmed/17083856

10. Di Landro, A. Family history, body mass index, selected dietary factors, menstrual history, and risk of moderate to severe acne in adolescents and young adults [Text] / A. Di Landro, S. Cazzaniga, F. Parazzini, V. Ingordo, F. Cusano, L. Atzori et. al. // Journal of the American Academy of Dermatology. - 2012. - Vol. 67, Issue 6. - P. 1129-1135. doi: 10.1016/j.jaad.2012.02.018

11. Melnik, B. C. Role of insulin, insulin-like growth-factor 1, hyperglycaemic food and milk consumption in the pathogenesis of acne vulgaris [Text] / B. C. Melnik, G. Schmitz // Experimental Dermatology. - 2009. - Vol. 18, Issue 10. - P. 833-841. doi: 10.1111/j.1600-0625.2009.00924.x

12. Melnik, B. Milk consumption: aggravating factor of acne and promoter of chronic diseases of Western societies [Text] / B. Melnik // Journal der Deutschen Dermatologischen Gesellschaft. - 2009. - Vol. 7, Issue 4. - P. 364-370. doi: 10.1111/j.16100387.2009.07019.x

13. Melnik, B. C. Evidence for acne-promoting effect of milk and other insulinotropic dairy products [Text] / B. C. Melnik // Nestle Nutrition Institute Workshop Series: Pediatric Program. - 2011. - Vol. 67. - P. 131-145. doi: 10.1159/000325580

14. Danby, F. W. Acne and milk, the diet myth, and beyond [Text] / F. W. Danby // Journal of the American Academy of Dermatology. - 2005. - Vol. 52, Issue 2. - P. 360-362. doi: 10.1016/j.jaad.2004.09.022

15. Saleha, N. Role of diet in acne [Text] / N. F. Saleh, S. A. Ramadan, O. M. Abu Zeid, R. A. Sabra, S. B. Abd El Aziz // Journal of the Egyptian Women's Dermatologic Society. - 2011. - Vol. 8, Issue 2. - P. 66-71. doi: 10.1097/01.ewx.0000397887.56807.4e

16. Smith, R. N. A low-glycemic-load diet improves symptoms in acne vulgaris patients: a randomized controlled trial [Text] / R. N. Smith, N. J. Mann, A. Braue, H. Makelainen, G. A. Varigos // The American Journal of Clinical Nutrition. - 2007. Vol. 86, Issue 1. - P. 107-115.

17. Smith, R. N. The effect of a high-protein, low glycemic-load diet versus a conventional, high glycemic-load diet on biochemical parameters associated with acne vulgaris: A randomized, investigator-masked, controlled trial [Text] / R. N. Smith, N. J. Mann, A. Braue, H. Makelainen, G. A. Varigos // Journal of the American Academy of Dermatology. - 2007. - Vol. 57, Issue 2. P. 247-256. doi: 10.1016/j.jaad.2007.01.046

18. Smith, R. N. The effect of a low glycemic load diet on acne vulgaris and the fatty acid composition of skin surface triglycerides [Text] / R. N. Smith, A. Braue, G. Varigos, N. J. Mann // Journal of Dermatological Science. - 2008. - Vol. 50, Issue 1. P. 41-52. doi: 10.1016/j.jdermsci.2007.11.005

19. Smith, R. N. A pilot study to determine the short-term effects of a low glycemic load diet on hormonal markers of acne: a nonrandomized, parallel, controlled feeding trial [Text] / R. Smith, N. Mann, H. Makelainen, J. Roper, A. Braue, G. Varigos // Molecular Nutrition \& Food Research. - 2008. - Vol. 52, Issue 6. - P. 718-726. doi: 10.1002/mnfr.200700307

\section{Дата надходження рукопису 14.03.2017}

Hanan Alghamdi, MD, department of dermatology, Imam abdulrahman Alfaisal University (IAU) and King Fahd Hospital of the University, PO Box 35312, Alkhobar 31488, KSA

E-mail: Hanan.alghamdi@outlook.com

Aisha M. Alhemel, MD, department of dermatology, Imam abdulrahman Alfaisal University (IAU) and King Fahd Hospital of the University, PO Box 35312, Alkhobar 31488, KSA

Iqbal A. Bukhari, professor, department of dermatology, Imam abdulrahman Alfaisal University (IAU) and King Fahd Hospital of the University, PO Box 40189, Alkhobar31952, KSA 